\title{
Reliability Model of Financial Reporting: Moderation and Mediation Effects
}

\author{
Abdul Halim* Ahmad Dahlan Gendut Budiwahyono \\ Faculty of Economics and Business, Universitas Gajayana Malang, Indonesia
}

\begin{abstract}
Public companies' financial report must be published formally as a means of management accountability to shareholders for the resources they manage. The reliability of financial report is important for stakeholders as a basis for economic decision making. Therefore, this study aims to build reliability the model of financial report. First model put competence and independence as independent variables and second model put professional supervision and professional commitment as a moderator, and third model put audit quality as mediator. The population is 398 public accountants who work for public accounting firms throughout East Java. The samples of 187 public accountants are selected by purposive sampling technique. Data were collected with a questionnaire and analyzed using partial least square. The conclusions can be stated as follows. The financial report reliability model was built from: first, competence and independence as independent variables affected audit quality; second, professional supervision and professional commitment were able to moderate (strengthen) the relationship of competence and independence with audit quality; third, audit quality was able to mediate (increase) the effect of competence and independence on financial report reliability.
\end{abstract}

Keywords: professional supervision, professional commitment, audit quality, financial report reliability

DOI: $10.7176 /$ RJFA/11-24-06

Publication date: December $31^{\text {st }} 2020$

\section{INTRODUCTION}

The country has a capital market to raise public fund to meet the emitters' need of funds. The economy is strongly influenced by the level of public confidence in the capital market. A well-managed capital market will provide investors with peaceful mind because their investments are safe and wisely used by emitters to improve stakeholders' welfare.

The reliability and accuracy of emitters' published financial statements including disclosure, is important to get investors' trust in the capital market. This trust can increase if the financial statement is audited by a public accountant. Public accountants should always maintain their audit quality based on Public Accountants' Professional Standards and Public Accountants' Professional Ethical Code for the survival of their clients, investors in the audited company, and the Public Accounting Firm itself. However, the reality is different. For example, in 2017 there was a fraud scandal in British Telecom. The impact of the accounting fraud had not only tainted the reputation of the PricewaterhouseCoopers (PwC), but it had also tarnished the public accountant profession. The public accountants' existence is very dependent on the public trust in public accountants' professional reputation. British Telecom immediately replaced PwC with Klynveld Peat Marwick Goerdeler (KPMG) (Priantara, 2017). This phenomenon indicated that the firm's audit quality is "low".

The Ministry of Finance of the Republic of Indonesia in 2018 imposed administrative sanctions on the Public Accountant Firm of Satrio, Bing, Eny \& Partners as Deloitte's affiliation in Indonesia. The Public Accountant Firm was subject to sanctions in the form of recommendations to make policies and procedures in the public accountant firm's quality control system related to the threat of senior team members' engagement when they audited the financial statement of PT Sunprima Nusantara Pembiayaan (SNP Finance). The public accountant firm was also required to implement audit policies and procedures and report their implementation no later than February 2, 2019. (Yudistira, 2018). This phenomenon indicated that the public accountant firm's audit quality is "low".

The window dressing case of PT Bank Bukopin Tbk's financial statement was revealed in 2018. Window dressing was carried out on credit card data of more than 100,000 cards in 2011-2016. The window dressing caused the position of credit and commission-based income of PT Bank Bukopin Tbk to improve unnaturally. KAP Purwantono, Sungkoro and Surja as the affiliation of Ernst and Young (EY) in Indonesia, showed that as public accountants their reputation was tainted (Banjarnahor, 2018). This phenomenon indicated that their audit quality is "low"

The exposed issues are the phenomena of problems showing that audits produced by public accountants had "low" quality. Thus it potentially created the uncertain reliability information presented in the audited financial statement. Higher audit quality shows that public accountants are able to detect the misstated material of financial statement, and it may reduce information asymmetry between principals and agents, and it is able to guarantee stakeholders' interests (Dang et al., 2004).

DeAngelo (1981) proved that audit quality was a combination of two possibilities that auditors were competent to detect or finding violations and misstated material in clients' financial reports; and they were 
independent auditors in reporting these findings. The audit quality model found by DeAngelo (1981) had been reexamined by several researchers, namely: Ramlah, et al. (2018), Amalia dkk. (2019), Daryaei \& Azizi (2018), dan Kertajasa dkk (2019)

The results of some researchers showed inconsistent conclusions. Jogiyanto (2014) found the previous studies that inconsistent, contradictory, conflicting results, either conflict of significance or direction may shows other variables that moderate the relationship. Therefore, the researcher includes the professional supervision and professional commitment as moderating variables of the relationship of competence and independence with audit quality. In addition, researcher also attributes audit quality as a mediating variable to the effect of competence and independence on financial reporting. This is the novelty of this research.

Professional supervision is a moderating variable with the consideration that supervision upon the public accountant profession with the obligation of maintaining and improving profession by continuous professional education, and it will be able to improve accountants' competence and independence, so that it gives the impact on higher audit quality (Quick and Warming-Rasmussen, 2001).

Professional commitment is used as a moderating variable with consideration that professional commitment is an important factor in an individual's behavior in a professional context. Public accountants with high levels of professional commitment tend to be more competent and independent in overcoming problems related to interrole conflict and remain focused on work and tend to be more obedient to the standards and rules set by the profession, thus this gives impact on high audit quality (Lui et al., 2001 and Jeffery \& Weatherholt, 1996).

Audit quality is used as a mediating variable with the consideration that qualified audit is seen as one of the factors that influence the credibility of financial report information (Becker et al., 1998 and Watkins et al., 2004); and reliable financial report can provide useful information for economic decision making (Shahwan, 2008). Qualified audit is able to minimize conflicts of interest between agents and principals, and it is able to maximize the credibility and reliability of financial report (Jerry and Saidu, 2017)

Based on the above description, the novelty or uniqueness of this research is to build a model of financial report based on the results of DeAngelo's (1981) research, by including professional supervision and professional commitment as a moderating variables for the influence of competence and independence on audit quality, and it links audit quality as a mediating variable of the influences competence and independence towards the reliability of financial report. Thus, the research question is what is the model of reliable financial report? Therefore, this study aims to build a model of financial report that consists of: first, competence and independence as independent variables; second, professional supervision and professional commitment as a moderating variable; third, audit quality as a mediating variable.

\section{REVIEW OF RELATED LITERATURE AND HYPOTHESIS DEVELOPMENT Reliability of Financial Reporting}

The concept of reliability in financial reporting shows the quality of financial information to convince economic decision makers that the information presented in financial reporting captures the actual condition of the reporter's entity events (Adediran, et al, 2013). The Statement of Financial Accounting Standards (SFAS) number 1 of 2018 stated that in order to become useful, the information presented in financial reporting must be reliable. It is said to be reliable if it is free from misleading notions, material errors, and it can be used reliably as a sincere and honest presentation of what should be presented. In this SFAS it is explained that there are 5 things contained in the concept of reliability of financial reporting, namely: (1) honest presentation, meaning that information must honestly describe transactions and other events that should be presented; (2) the substance exceeds the form, meaning that the transaction or event needs to be recorded and presented in accordance with the substance and economic relations and not just the legal form; (3) neutrality, meaning that information must be directed to the general needs of users and not depend on the needs and desires of certain parties; (4) sound considerations, containing the element of prudence when making estimates under conditions of uncertainty, so that assets and income are not declared too high, and (4) sound considerations, containing an element of prudence when making estimates under conditions of uncertainty, so that assets and income are not declared too high, and liabilities and expenses are not declared too low; (5) completeness, meaning that information in financial reporting must be complete within the limits of materiality and cost.

\footnotetext{
Audit Quality

DeAngelo (1981) stated that audit quality was a combination of the possibility that the auditor was competent to detect or finding material misstatements and misstatements in the client's financial reporting and was independent in reporting the findings. Furthermore, Davidson and Neu (1993) proved that audit quality showed the auditor's ability to detect and eliminate material misstatements and manipulation in financial reporting, which has an impact on the reliability of financial reporting.

Tontiset \& Kaiwinit (2018) proved that the higher the audit quality, the more likely the company will get the reliability of financial reporting, including: (a) predictive value; (b) confirmative value; (c) entity-specific material;
} 
(d) completeness; (e) neutrality; (f) free from error; and (g) verifiability. Furthermore, Gerayli et al., (2011) prove that high quality audits can improve the reliability of financial information, because it can easily identify and report on policies in reported earnings. La Porta et al., (1998) and Memis and Cetenak (2012) in their research concluded that quality audits limit management's flexibility in earnings management practices and quality audits facilitate investors in accessing reliable financial information.

Audit quality is very important because it increases public confidence in the reliability of financial reporting, as a result of the independence and ethical behavior of auditors towards their clients (Hamid and Suzana, 2013); and audit quality reflects the auditor's activity in gathering sufficient evidence, detecting fraudulent activities, reducing manipulation of financial information, ultimately increasing the reliability of clients' financial reporting (Soliman and Ragab, 2014). Some of these findings indicate that audit quality affects the reliability of financial reporting,

Based on this explanation, the first hypothesis is as follows:

H1: Audit quality affects the reliability of financial reporting

\section{Competence}

Lasmahadi (2012) explained that competence showed the personal attributes of a person to enables him to achieve superior performance. These personal attributes include the nature, motives, value systems, attitudes, knowledge, experience, and skills. Competence will direct behavior, while behavior will produce performance. However, not all personal attributes of a person are competencies, only personal attributes that drive themselves to achieve superior performance are the competencies they have.

Mendonca and Persson (2014) proved that auditor competency/quality and auditor independence / characteristics were one of audit quality drivers. Wooten (2003) and Watkins et al. (2004) proved that the auditor's competence in finding and eliminating material and manipulation in financial statements affects audit quality. Lee and Stone (1995) proved that auditor competency and independence influence audit quality.

Wong and Chueng (2008) stated that continuous improvement of auditors showed the characteristics of auditor learning, where knowledge is obtained through continuing education and training on accounting and auditing that have an impact on increasing auditor competence which also has an impact on audit quality. Francis (2011) proved that audit quality will be higher if auditors who carry out audits have high competence and independence. Conversely, lack of competence and independence will interfere with the auditor's ability to apply objective assessments and it influences trust in the audit process which results in poor audit quality.

Based on these explanations, the second, third, and fourth hypotheses are as follows:

$\mathrm{H} 2$ : competence influences audit quality

H3: Competence influences the reliability of financial reporting

H4: competence influences the reliability of financial reporting through audit quality

\section{Independence}

Bartlett (1993), Maury (2000), and Sridharan et al. (2002) suggested that auditor independence was unbias auditor's mental attitude in decision making throughout the audit and reporting. DeAngelo (1981b) written that independence was auditors' courage to tell 'the truth when the truth was bad news' from the client's perspective. If the auditor is not independent of his client, his opinion will not provide any additions (Mautz and Sharaf, 1993).

Mendonca and Persson (2014) proved that auditor competency/quality and auditor independence / characteristics were one of the audit quality drivers. Ussahawanitchakit (2011) documented that audit experience, audit independence and audit professionalism had the potential to have a positive impact on audit performance and audit quality. Wooten (2003) and Watkins et al. (2004) proved that auditor independence was an important factor to influence the audit quality and the auditor's ability to report the material misstatements.

Mojtahedzadeh and Aghaei (2005) documented that auditor independence was a determining factor in the public accounting profession. Lee and Stone (1995) found influence between auditor independence and competence on audit quality. Without independence, audit opinion was meaningless. Therefore, the success of an audit was largely dependent on the auditor independence. Hussey and Lan (2001) documented that an audit can only be qualified if the auditor was independent to report the agreement violations between the principal and agent. These findings indicate that the auditor's independence affects the audit quality.

Francis (2011) made a research to understand and examine audit quality. He found that audit quality will be higher if the auditors who conduct audits were competent and independent. Conversely, a lack of competence and independence will interfere with the auditor's ability to apply objective assessments and influence confidence in the auditing process which results in poor audit quality.

Based on this explanation, the fifth, sixth, and seventh hypotheses are as follows:

H5 : Independence influences audit quality

H6 : independence influences the reliability of financial reporting

$\mathrm{H} 7$ : Independence influences the reliability of financial reporting through audit quality 


\section{Professional Supervision}

Professional supervision is defined as strict regulations in setting standards, law enforcement, accuracy mechanisms, effectiveness of authoritative guidelines provided by accounting and auditing standards, codes of ethics, and sanctions imposed for ethical violations. The existence of guidelines, standards, regulations, sanctions and requirements of the audit profession, is one of the media of supervision of the auditor profession. If auditors follow the ethical code, their appreciation for professional values increases, it is likely that independence and competence will increase which impacts on audit quality (Greenfield, 2005).

Imposed sanction serves as effective barriers to the auditor's unethical behavior and such sanction is incentive to increase auditor competence and independence that have an impact on audit quality (Raymond and Kong, 2005). The enforcement of ethical guidelines is aimed at resolving ethical dilemmas (Citron and Taffler, 2001).

Based on this explanation, it can be stated that if professional supervision is interacted with competence and independence, then it is considered to be able to strengthen the relationship of competence and independence with audit quality; so the eighth and ninth hypotheses are as follows:

H8 : professional supervision strengthens the relationship of competence with audit quality

H9 : Professional supervision strengthens the relationship of independence with audit quality.

\section{Professional Commitment}

Related to auditor profession, Gendron et al. (2006) defined professional commitment as the extent to which the individual auditor considers standards and codes of ethics as key attributes of the profession and believes that these standards and codes must be strictly binding and enforced in the domain of public accountants. Hall et al. (2005) explained that the commitment of the public accountant profession was conceptualized as a construction of three aspects, namely: (1) normative commitment, regarding the auditor's feelings must remain in his profession, (2) continuous commitment, regarding an auditor's awareness must be in his profession, because the costs or losses that must be borne by the auditor (for example financial losses) in connection with the auditor's departure from his professional organization; and (3) affective commitment, regarding the desire to want to be in his profession, because the auditor feels to have an emotional bond or have the same values as the professional organization.

Greenfield et al. (2007) proved that high professional commitment can be a contributing factor in forming auditor competence and independence. Greenfield (2005) documented that a higher level of professional commitment was associated with positive behavior that beneficial to organizations and individuals. Higher level of professional commitment motivates the auditor to avoid activities that detrimental to an organization. Yetmar (2005) proved that high professional commitment was reflected in sensitivity to professional ethical issues to affect auditor independence.

Gunz and Gunz (1994) proved that to become a true professional, one must have high professional commitment by investing a lot of time and energy in learning and practicing their professional knowledge and skills. Therefore, knowledge and skills are the basis of professionalism that can improve professional competence.

Based on this explanation, it can be argued that professional commitment is interacted with competence and independence. It is allegedly can strengthen the relationship of competence and independence with audit quality; thus the tenth and eleventh hypotheses are as follows:

H10 : professional commitment strengthens the relationship of competence with audit quality

H11 : professional commitment strengthens the relationship of independence with audit quality

\section{RESEARCH METHODS}

\section{Population and Sample}

This research population was 375 public accountants at Public Accounting Firms in East Java. Using a purposive sampling technique, the junior public accountants were excluded and the selected samples were 187 public accountants.

\section{Data}

This study used primary data in the form of public accountants' perceptions of: competence, independence, audit quality, professional supervision, professional commitment, and financial reporting reliability. The data source was 187 public accountants as respondents. The data were collected by questionnaires given directly to respondents by researcher's colleague (public accountants) who work in the public accountant firm.

Research Variables, Indicators, Measurement Scale and Questionnaire Reference

Research variables, indicators, measurement scales and questionnaire references are presented in Table 1. 
Table 1

Research Variable, Indicator, Measurement Scale and Questionnaire References

\begin{tabular}{|c|c|c|c|c|}
\hline No & Variable & Indicator & $\begin{array}{l}\text { Measurement } \\
\text { Scale }\end{array}$ & Questionnaire References \\
\hline 1 & $\begin{array}{l}\text { Auditor } \\
\text { Competence } \\
\left(\mathrm{X}_{1}\right)\end{array}$ & $\begin{array}{l}\mathrm{X}_{1.1}=\text { plan } \\
\mathrm{X}_{1.2}=\text { knowledge } \\
\mathrm{X}_{1.3}=\text { experience } \\
\mathrm{X}_{1.4}=\text { supervision }\end{array}$ & $\begin{array}{l}\text { Interval } \\
\text { Interval } \\
\text { Ratio \& Interval } \\
\text { Interval }\end{array}$ & $\begin{aligned} \mathrm{X}_{1.1}= & \text { Dikolli }(2004) \\
\mathrm{X}_{1.2}= & \text { Finance MinistryRule } \\
& \text { No.17/PMK.01/2008 } \\
\mathrm{X}_{1.3}= & \text { Colbert }(1989) \\
\mathrm{X}_{1.4}= & \text { Patten }(1995)\end{aligned}$ \\
\hline 2 & $\begin{array}{l}\text { Independence } \\
\text { Auditor }\left(\mathrm{X}_{2}\right)\end{array}$ & $\begin{aligned} \mathrm{X}_{2.1}= & \text { competition in } \\
& \text { audit market } \\
\mathrm{X}_{2.2}= & \text { economic dependence } \\
\mathrm{X}_{2.3}= & \text { non-audit service } \\
\mathrm{X}_{2.4}= & \text { auditor duty time }\end{aligned}$ & $\begin{array}{l}\text { Interval } \\
\text { Rasio \& Interval } \\
\text { Interval } \\
\text { Ratio }\end{array}$ & $\begin{array}{l}\mathrm{X}_{2.1}=\text { Beattie } \text { et al.(1999) } \\
\mathrm{X}_{2.2}=\text { Beattie } \text { et al.(1999) } \\
\mathrm{X}_{2.3}=\text { Schneider } \text { et al. }(2006) \\
\mathrm{X}_{2.4}=\text { Shafie } \text { et al. }(2009)\end{array}$ \\
\hline 3 & $\begin{array}{l}\text { Professional } \\
\text { Supervision } \\
\left(\mathrm{X}_{3}\right)\end{array}$ & $\begin{aligned} \mathrm{X}_{3.1}= & \text { accounting } \\
& \text { standard } \\
\mathrm{X}_{3.2}= & \text { professional } \\
& \text { standard } \\
\mathrm{X}_{3.3}= & \text { ethical code of } \\
& \text { profession } \\
\mathrm{X}_{3.4}= & \text { imposed sanction on } \\
& \text { ethic violation } \\
\mathrm{X}_{3.5}= & \text { certainty of } \\
& \text { profession } \\
& \text { maintenance }\end{aligned}$ & $\begin{array}{l}\text { Interval } \\
\text { Interval } \\
\text { Interval } \\
\text { Interval } \\
\text { Interval }\end{array}$ & $\begin{array}{l}X_{3.1}, X_{3.2}, X_{3.3}, X_{3.4}, \text { dan } X_{3.5} \\
\text { refers to Boatham dan } \\
\text { Ussahawanitchakit }(2009)\end{array}$ \\
\hline 4 & $\begin{array}{l}\text { Professional } \\
\text { Commitment } \\
\left(\mathrm{X}_{4}\right)\end{array}$ & $\begin{aligned} \mathrm{X}_{4.1}= & \text { normative profe- ssional } \\
& \text { commitment } \\
\mathrm{X}_{4.2}= & \text { continuous } \\
& \text { professional } \\
& \text { commitment } \\
\mathrm{X}_{4.3}= & \text { affective } \\
& \text { professional } \\
& \text { commitment }\end{aligned}$ & $\begin{array}{l}\text { Interval } \\
\text { Interval } \\
\text { Interval }\end{array}$ & $\begin{array}{l}\mathrm{X}_{4.1}, \mathrm{X}_{4.2} \text {, dan } \mathrm{X}_{4.3} \text { refers to } \\
\text { Smith and Hall }(2008) \\
\text { and Silaban (2009) }\end{array}$ \\
\hline 5 & $\begin{array}{l}\text { Audit Quality } \\
\left(\mathrm{Y}_{1}\right)\end{array}$ & $\begin{aligned} \mathrm{Y}_{1.1}= & \text { auditor reputation } \\
\mathrm{Y}_{1.2} & =\text { industry specialist } \\
& \text { auditor }\end{aligned}$ & $\begin{array}{l}\text { Ratio \&Interval } \\
\text { Ratio \& Interval }\end{array}$ & $\begin{aligned} \mathrm{Y}_{1.1}= & \text { Vallens }(2008) \\
\mathrm{Y}_{1.2}= & \text { Gramling et al. }(2001) \\
& \text { dan Craswell et al. }(1995)\end{aligned}$ \\
\hline 6 & $\begin{array}{l}\text { Reliability of } \\
\text { Financial } \\
\text { Reporting } \\
\text { (Y2) }\end{array}$ & $\begin{aligned} \mathrm{Y}_{2.1}= & \text { honest } \\
& \text { presentation } \\
\mathrm{Y}_{2.2}= & \text { substance excels form } \\
\mathrm{Y}_{2.3}= & \text { neutrality } \\
\mathrm{Y}_{2.4}= & \text { sound consideration } \\
\mathrm{Y}_{2.5}= & \text { completeness }\end{aligned}$ & $\begin{array}{l}\text { Interval } \\
\text { Interval } \\
\text { Interval } \\
\text { Interval } \\
\text { Interval }\end{array}$ & $\begin{array}{l}\mathrm{Y}_{2.1}, \mathrm{Y}_{2.2}, \mathrm{Y}_{2.3}, \mathrm{Y}_{2.4} \text {, dan } \mathrm{Y}_{2.5} \\
\text { refers to Statement of } \\
\text { Financial Accounting Standard } \\
(\mathrm{SFAS}) \text { no. } 1(2018)\end{array}$ \\
\hline
\end{tabular}

\section{Analysis Technique}

Data analysis technique was Partial Least Square (PLS) with the consideration that PLS was developed in the situation where the theory was weak, powerful and can be applied to all types of data scales; it does not require a lot of assumptions; the sample size should not be large; and variables can be reflective or formative. Besides, PLS can be used both to confirm the theory and to recommend relationship between variables that exist or are suspected to exist if the basic conception or empirical support is weak. Before data were analyzed, tests were first performed: validity, reliability, linearity, and goodness of fit models (Solimun, 2010 ).

\section{RESEARCH RESULTS AND DISCUSSION}

Results of Validity, Reliability, Linearity, and Goodness of Fit Model Test

The validity test was done by Pearson correlation. P-value smaller than 0.05 means that the items in the questionnaire are valid. Meanwhile, the reliability test was done by Alpha Cronbach. The score above 0.6 indicates 
the items in the questionnaire were reliable. Furthermore, the linearity assumption was tested by curve fit method, resulted in the sig value of the linear model for nine hypotheses smaller than 0.05 for all possible models. These results indicated that the model was linear. Goodness of fit test produces $\mathrm{R}^{2}$ value of 0.8531 or predictive relevance value of 85.31 percent. It shows that the information within data can explain the model at 85.31 percent. The remaining 14.69 percent is explained by other variables outside the model and error term. All test results above are good for PLS model. Thus, the PLS model can be used for hypothesis testing.

\section{Result of Hypothesis Testing}

Results of hypothesis testing using PLS are presented on Table 2.

Table 2

Summarized Result of Hypothesis Testing Using PLS

\begin{tabular}{|c|c|c|c|}
\hline Description & $\begin{array}{c}\text { Coefficient } \\
\text { inner weight }\end{array}$ & $p$-value & $p$ value $<0.05$ \\
\hline $\mathrm{Y} 1=>\mathrm{Y} 2$ & 4.176 & 0.000 & H-1 accepted \\
\hline $\mathrm{X} 1=>\mathrm{Y} 1$ & 3.432 & 0.000 & H-2 accepted \\
\hline $\mathrm{X} 1=>$ Y2 (direct influence) & 4.564 & 0.000 & H-3 accepted \\
\hline $\mathrm{X} 1=>\mathrm{Y} 1 \Rightarrow \mathrm{Y} 2$ (indirect influence) & \multicolumn{2}{|c|}{$3.432 * 4.176=14.332>4.564$} & H-4 accepted \\
\hline $\mathrm{X} 2=>\mathrm{Y} 1$ & 3.453 & 0.000 & H-5 accepted \\
\hline $\mathrm{X} 2=>$ Y2 (direct influence) & 5.723 & 0.000 & H-6 accepted \\
\hline $\mathrm{X} 2 \Rightarrow \mathrm{Y} 1 \Rightarrow \mathrm{Y} 2$ (indirect influence) & \multicolumn{2}{|c|}{$3.453 * 4.176=14.420>5.723$} & H-7 accepted \\
\hline $\mathrm{X} 1 * \mathrm{X} 3=>\mathrm{Y} 1$ & 2.845 & 0.000 & H-8 accepted \\
\hline $\mathrm{X} 2 * \mathrm{X} 3=>\mathrm{Y} 1$ & 2.675 & 0.000 & H-9 accepted \\
\hline $\mathrm{X} 1 * \mathrm{X} 4=>\mathrm{Y} 1$ & 2.657 & 0.000 & H-10 accepted \\
\hline $\mathrm{X} 2 * \mathrm{X} 4=>\mathrm{Y} 1$ & 2.654 & 0.000 & H-11 accepted \\
\hline
\end{tabular}

Source: primary data processed by the researcher using PLS

Table 2 shows that the coefficient of inner weight shows direct effect $\mathrm{X} 1=>\mathrm{Y} 2$ is 4,564 ; and the inner weight coefficient of indirect effect $\mathrm{X} 1=>\mathrm{Y} 1=>$ indicates $\mathrm{Y} 2$ is $14,332(=3,432 * 4,176)$. Likewise, the inner weight coefficient of direct influence $\mathrm{X} 2=>\mathrm{Y} 2$ is 5,723; and the inner weight coefficient of indirect effect $\mathrm{X} 2 \Rightarrow \mathrm{Y} 1 \Rightarrow$ $\mathrm{Y} 2$ is $14,420(=3,453 * 4,176)$. The value of the inner weight coefficient of indirect influence, both $\mathrm{X} 1 \Rightarrow \mathrm{Y} 1 \Rightarrow$ $\mathrm{Y} 2$ and $\mathrm{X} 2=>\mathrm{Y} 1=>\mathrm{Y} 2$, shows greater than the inner weight coefficient of direct influence, both $\mathrm{X} 1=>\mathrm{Y} 2$ and $\mathrm{X} 2=>\mathrm{Y} 2$, so it can be stated that Audit quality as a mediating variable can increase the effect of competence and independence on the reliability of financial reporting

Table 2 shows that the inner weight coefficient $\mathrm{X} 1 * \mathrm{X} 3=>\mathrm{Y} 1$ is positive with $\mathrm{p}$-value $0.000<0.05$ and inner weight coefficient $\mathrm{X} 2 * \mathrm{X} 3=>\mathrm{Y} 1$ is positive with $\mathrm{p}$-value $0.000<0.05$. This means that professional supervision as a moderating variable is able to strengthen the relationship of competence and independence of audit quality.

Table 2 shows that the inner weight coefficient $\mathrm{X} 1 * \mathrm{X} 4=\mathrm{Y} 1$ is positive with $\mathrm{p}$-value $0,000<0.05$ and inner weight coefficient $\mathrm{X} 2 * \mathrm{X} 4=>\mathrm{Y} 1$ is positive with $\mathrm{p}$-value $0,000<0.05$. This means that professional commitment as a moderating variable is able to strengthen the relationship of competence and independence of audit quality.

\section{Discussion}

Based on the results of hypothesis testing, a model of reliability of financial reporting: the effects of moderation and mediation are presented in Figure 1. 


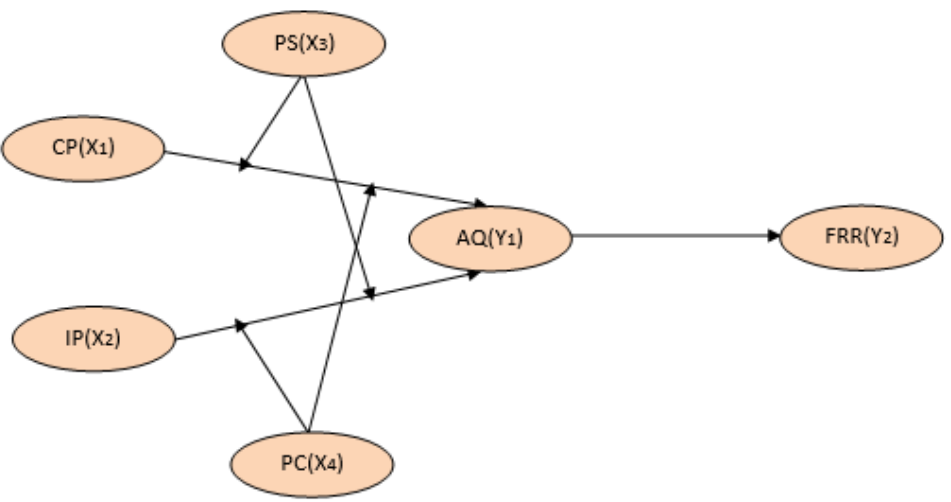

Figure 1

$\begin{array}{ll}\text { CP } & =\text { Competence } \\ \text { IP } & =\text { Independence } \\ \text { AQ } & =\text { Audit Quality } \\ \text { PS } & =\text { Professional Supervision } \\ \text { PC } & =\text { Professional Commitment } \\ \text { FRR } & =\text { Financial Reporting Reliability }\end{array}$

This study results prove that audit quality as a mediating variable can increase the effect of competence and independence on financial reporting reliability. Therefore, public accountants should improve their audit quality by specializing in certain industries. Lowensohn et al. (2007) proved that there was a positive relationship between public accountants specializing in certain industries and audit quality. In addition, public accountants who specialize in certain industries are important factors related to audit quality. They have superior knowledge, and specialized public accountants make expensive investments in certain industry knowledge, thus this enables them to offer different audit products, namely qualified audits (Cahan et al., 2008).

Specialized public accountants can also improve Public Accountant Firm's efficiency through economic scale resulting from investments that are concentrated in specialized industrial resources and technology. In addition, specialized public accountants can more effectively find faults and more accurately assess audit risk that give impacts on audit quality (Owhoso et al., 2002, Beasley and Petroni, 2001). Specialized public accountants make it possible to gain more in-depth knowledge about business, operations, and client risks compared to non-specialists (Bell et al., 2005).

Neal and Riley (2004) proved that the respected accountant specializing in certain industries was reflected by Public Accountant Firms ability to differentiate themselves from their competitors in the market share of certain industries. Public Accountant Firms with the largest market share have the greatest knowledge in certain industries and significant market share in certain industries reflects significant investment by Public Accountant Firms in developing audit technology related to specific industry with the benefit of improving audit quality.

This study results prove that professional supervision as a moderating variable can strengthen the relationship of competence and independence with audit quality which has an impact on improving the reliability of financial reporting. Therefore, the Financial Professional Development Center should further increase the supervision of the public accountant profession by tightening standards, law enforcement, accuracy mechanisms, effectiveness of accounting standard guidelines, professional standards, professional code of ethics, and sanctions imposed for ethical violations, as the monitoring media. The changing accounting environment has an impact on the importance of reviewing professional standards and ethics so that the quality of the resulting audit can be guaranteed so that it gives impacts to the financial reporting constraints.

This study results proved that professional commitment as a moderating variable can strengthen the relationship of competence and independence with audit quality which has an impact on improving the reliability of financial reporting. Therefore, public accountants need to understand the construct of their professional commitment, covering three aspects, namely: (1) normative professional commitment, that the public accountant receives significant benefits from his profession, (2) continuous professional commitment, that public accountants need investment to obtain his profession, and (3) affective professional commitment, that public accountants gain positive development of their professional expertise (Hall et al., 2005).

Individuals with normative professional commitments and high affective professional commitments are more likely to be engaged in professional activities and to keep up to date with the development of their profession; they can meet the minimum requirements to maintain their membership, thereby affecting auditor competence and independence which give impacts on audit quality and financial reporting reliability. While individuals with high 
continuous professional commitment tend to be willing to do anything that is not specifically required (Meyer et al., 1993)

\section{CONCLUSION AND SUGGESTIONS \\ Conclusion}

This study concluded that the reliability model in financial reporting shows following results. First, competence and independence as independent variables affected audit quality. Second, professional supervision and professional commitment can moderate (strengthen) the relationship of competence and independence with audit quality. Third, audit quality can mediate (increase) the effect of competence and independence on financial reporting.

\section{Suggestions}

Related to audit quality, public accountants should become specialized public accountants. Public accountants who are specialized in or are often tasked with specific auditing / specific industries, will become very adept at identifying and addressing specific industry audit issues, so that they can produce qualified audits that have an impact on the reliability of financial reporting.

Related to professional supervision, the Financial Professional Development Center of the Ministry of Finance of the Republic of Indonesia should make improvements and adjustments to the media or indicators used to carry out professional supervision in order to be able to answer the progress of the business world. The media or indicators include: accounting standards, professional standards, professional code of ethics, sanctions imposed on violations of ethics, and provisions for professional maintenance.

Related to professional commitments, public accountants should better understand the constructs of professional commitments, namely: (1) normative professional commitment, because this commitment implies that public accountants feel an obligation that is appropriate for the benefits provided by the organization of his profession; (2) continuous professional commitments, because this commitment implies the existence of losses that must be borne by the auditor (for example financial losses) in connection with a public accountant leaving his professional organization; (3) affective professional commitment, because this commitment implies that public accountants feel that they have emotional ties or have the same values as their professional organizations.

\section{REFERENCE}

Amalia, F.A., Sutrisno, and Baridwan, Z. (2019). Audit Quality: Does Time Pressure Influence Independence and Audit Procedure Compliance of Auditor? , Journal of Accounting and Investment, vol. 20 no. 1, January 2019, 130-144

Banjarnahor, D. (2018). Drama Bank Bukopin: Kartu Kredit Modifikasi dan Rights Issue. CNBC Indonesia.

Bartlett, R. W. (1993). A Scale of Perceived Independence: New Evidence on an Old Concept. Accounting, Auditing \& Accountability Journal, 6, 52-67.

Beasley, M., and Petroni, K. 2001. Board independence and Audit-firm Type. Auditing: A Journal of Practice and Theory, (March) 20 (1), 97-114.

Beattie, V., Brandt, R., and Fearnley, S. (1999). Perceptions of Auditor Independence: UK Evidence. Journal of International Accounting, Auditing \& Taxation, 8 (1), 67-107.

Becker, C. L., DeFond, M. L., Jiambalvo, J., and Subramanyam, K. R. (1998). The Effect of Audit Quality on Earnings Management. Contemporary Accounting Research, 15 (1), 1-21.

Bell, T. B., Peecher, M. E., and Solomon, I. (2005). The 21st Century Public Accounting Audit. KPMG International.

Cahan, S. F., Godfrey, J. M., Hamilton, J., and Jeter, D. C. (2008). Auditor Specialization, Auditor Dominance, and Audit Fees: The Role of Investment Opportunities. The Accounting Review, (Nov.) 83 (6), 1393-1424.

Citron, D. B., and Taffler, R. J. (2001). Ethical Behaviour in the U.K. Audit Profession: The Case of the SelfFulfilling Prophecy Under Going-Concern Uncertainties. Journal of Business Ethics, 29, 353-363.

Colbert, J. L. (1989). The Effect of Experience Auditor's Judgments. Journal of Accounting Literature, 8, 137-149.

Craswell, A., Francis, J., and Taylor, S. (1995). Auditor Brand Name Reputations and Industry Specializations. Journal of Accounting \& Economics, 20, 297-322.

Dang, L., Brown, K. F., and McCullough, B. D. (2004). Assessing Actual Audit Quality: A Value Relevance Perspective, Working Paper. http://www.ssrn.com

Daryaei, A. A., and Azizi, A. (2018). The Impact Of Ethics, Experience And Competency On Audit Quality (With Auditors Professional Skepticism As A Moderating Variable), The Journal of Financial Accounting Knowledge, Volume 5, Issue 1 - Serial Number 16, Spring, 79-99

Davidson, R. A., and Neu, D. (1993). A Note on Association between Audit Firm Size and Audit Quality. Contemporary Accounting Research, 9 (2),479-488.

DeAngelo, L. E. (1981). Auditor Size and Auditor Quality. Journal of Accounting \& Economics, (Dec.) 3, 183- 
199.

---------. 1981b. Auditor Independence, "Low Balling" and Disclosure Regulation. Journal of Accounting \& Economics, (August.), 113-127.

Dikolli, S. S., McCracken, A. M., and Walawski, J. B. M. (2004). Audit-Planning Judgments and ClientEmployee Compensation Contracts. Behavioral Research in Accounting, Sarasota, 16, 45-62

Francis, J. R. (2011). A Framework for Understanding and Researching Audit Quality. Auditing: A Journal of Practice \& Theory, 30 (2), 125-52.

Gendron Y. R., Suddaby, and Lam, H. (2006). an Examination of the Ethical Commitment of Professional Accountants to Auditor Independence. Journal of Business Ethics, 64, 169-193

Gerayli, M. S., Yanesari, A. M., and Ma'atoofi, A. R. (2011). Impact of Audit quality on Earnings Management: Evidence from Iran. International Research Journal of Finance and Economics, 66, 77-84

Gramling, J. M., and Stone, R. M. (2001). Audit Firm Industry Expertise: A Review And Synthesis of The Archival Literature. Journal of Accounting Literature, 20, 1-15

Greenfield, A. C. (2005). Introducing an Ethical Dimension into the Earnings Management Decision. Commonwealth University, Virginia

Greenfield, A. C., Norman, C. S., and Wier, B. (2007). the Effect of Ethical Orientation and Professional Commitment on Earnings Management Behavior. Journal of Business Ethics, 75, 175-198.

Gunz H. P., and Gunz, S. P. (1994). Professional Organizational Commitment and Job Satisfaction for Employed Lawyers. Humman Relatation Journal, 47 (7), 801-827

Hall, M., Smith, D., and Smith, K. L. (2005). Accountant's Commitment to Their Profession: Multiple Dimensions of Professional Commitment and Opportunities for Future Research. Behavioral Research Accounting, 17 , 89-109

Hamid, A., and Suzana, S. (2013). The Impact of Audit Quality on Accounting Conservatism in Financial Reporting of Malaysian Listed Companies, $4^{\text {th }}$. International Conferences on Business and Economic Research Proceeding, 1345-1361.

Hussey, R., and LAN, G. (2001). An Examination of Auditor Independence Issues from the Perspectives of U.K. Finance Directors. Journal of Business Ethics, (Springer) 32 (2), 169-178.

Jeffrey, C., and Weatherholt, N. (1996). Ethical Development, Professional Commitment and Rule Observance Attitudes: A Study of CPAs and Corporate Accountants. Behavioral Research in Accounting, 8, 8-31.

Jerry, M., and Saidu, A. (2017). The Impact of Audit Firm Size on Financial Reporting Quality of Listed Insurance Companies in Nigeria. Iranian Journal of Accounting, Auditing \& Finance, 2 (1): 19-47

Jogiyanto. (2014). Metodologi Penelitian Bisnis: salah kaprah dan pengalaman-pengalaman. BPFE, Yogyakarta Kertarajasa, A. Y., Marwa, T., and Wahyudi T. (2019). The Effect of Competence, Experience, Independence, Due Professional Care, And Auditor Integrity on Audit Quality with Auditor Ethics as Moderating. Journal of Accounting, Finance and Auditing Studies, 5/1, 80-99

La Porta, R., F., Lopez-de-Silanes, and Shleifer, A. (1998). Law and Finance. The Journal of Political Economy, 106 (6), 1113-1155.

Lasmahadi, A. (2012). Sistem Manajemen SDM Berbasis Kompetensi. http//:www.e-psikologi.com

Lee, T. A., and Stone, M. (1995). Competence and Independence: the Uncongenial Twins of Auditing?. Journal of Business Finance \& Accounting, 1169-1177.

Lowensohn, S. L., Johnson, E., Elder, R. J., and Davies, S. P. (2007). Auditor Specialization, Perceived Audit Quality, and Audit Fees in the Local Government Audit Market. Journal of Accounting \& Public Policy, 26, 705-732

Lui, S., Ngo, J., and Tsang, A. (2001). Inter-Role Conflict as a Predictor of Job Satisfaction and Propensity to Leave: A Study of Professional Accountants. Journal of Managerial Psychology, 16 (5/6), 469-484.

Maury, M. D. (2000). A Circle of Influence: Are All the Stakeholders Included.? Journal of Business Ethics, 23: 117-121.

Mautz, R. K., and Sharaf, H. A. (1993). The Philosophy of Auditing. American Accounting Association. Working Paper. http://www.ssrn.com.

Memis, M. U., and Cetenak, E. H. (2012). Earnings Management, Audit Quality and Legal Environment: An International Comparison. International Journal of Economics and Financial Issues, 2 (4), 460-469

Mendonca, H. S., and Persson, L. (2014). Audit Quality from a Client Company Perspective-Drivers of audit quality and the Effects of a Voluntary Audit Firm Rotation. Master Thesis. Gothenburg University.

Meyer, J. P., Allen, N. J, and Smith, C. A. (1993). Commitment to Organizational and Accupatios: Extensions and Test of a Three-Component Conceptualization. Journal of Applied Psychology, 78 (4), 538-551

Mojtahedzadeh, V., and Aghaei, P. (2005). Factors Affecting on Independent Audit Quality: From the View Point of Auditors and Users. The Iranian Accounting and Auditing Review, 11 (38), 53-76.

Oizer, P. (1998). Company Directors' Views on the Performance of the 1987 Big Eight and The 1996 Big Six. Leeds University Business School. Working Paper. http://www.ssrn.com 
Neal, T. L., and Riley Jr., R. R. (2004). Auditor Industry Specialist Research Design. Auditing: A Journal of Practice \& Theory, 23 (2), 169-179.

Owhoso, V. E., Messier Jr., W. F., and Lynch Jr. J. G. (2002). Error Detection by Industry-Specialized Teams During Sequential Audit Review. Journal of Accounting Research, (June) 40, 883-900

Patten, D. M. (1995). Supervisory Action and Job Satisfaction: An Analysis of Differences between Large and Small Public Accounting Firms. Accounting Horizon, 9 (2), 405-420

Priantara, D. (2017). Ketika Skandal Fraud Akuntansi Menerpa British Telecom dan PwC. https://www.wartaekonomi.co.id

Quick, R., and Worming-Rasmussen, B. (2002). Disciplinary Observance and Sanctions on German and Danish Auditors. International Journal of Auditing, 6, 133-153

Ramlah., Syah, A., and Dara, M. A. (2018). The Effect of Competence and Independence to Audit Quality with Auditor Ethics as a Modernation Variable. International Journal Of Scientific \& Technology Research, 7 (9, 6-10

Raymond, W., and Kong, M. (2005). An Empirical Study of Audit Quality in China from the Perspectives of Regulators and the Accounting Profession. Polytechnic University, Hong Kong

Schneider, A., Chruch, B. K., and Ely, K. M. (2006). Non-Audit Services and Auditor Independence: A Review of the Literature. Journal of Accounting Literature, Gainesville, 25, 169-12

Shahwan, Y. (2008). Qualitative Characteristics of Financial Reporting: A Historical Perspective. Journal of Applied AccountinResearch, 9 (3), 192-202.

Shafie, R. W., Hussin, N. W., Md-Yusof, M. A., and Md-Hussain, M. H. (2009). Audit Firm Tenure and Auditor Reporting Quality: Evidence in Malaysia. International Business Research, (April) 2 (2), 99-109

Silaban, A. (2009). Perilaku Disfungsional Auditor dalam Pelaksanaan Program Audit. DISERTASI. Program Doktor Ilmu Ekonomi, Universitas Diponegoro. Semarang.

Smith, A. and Hall, M. (2008). An Empirical Examination of a Three Component Model of Prefesional Commitment among Public Accountant. Behavioral Research Accounting, 20 (1), 75-92

Solimun. (2010). Analisis Multivariat Pemodelan Struktural: Metode PARSIAL Least Square-PLS. CV. Citra, Malang

Soliman, M., and Ragab, A. (2014). Audit Committee Effectiveness, Audit Quality and Earnings Management: An Empirical Study of the Listed Companies in Egypt. Research Journal of Finance and Accounting, 5 (2), 155-166.

Sridharan, U. V., Caines, W. R., McMillan, J., and Summers, S. (2002). Financial Statement Transparency and Auditor Responsibility: Enron and Andersen. International Jornal of Auditing, 6, 277-286.

Tontiset, N., and Kaiwinit, S. (2018). The Factors Affecting Financial Reporting Reliability: an Empirical R esearch of Public Listed Companies in Thailand. Journal of Modern Accounting and Auditing, 14 (6), 291304

Ussahawanitchakit, P. (2011). Audit Practice and Audit Performance of CPAs in Thailand. Journal of Academic Business and Econonomic, 44-60.

Vallens, A. (2008). The Importance of Reputation. Risk Management Journal. Iss. 16, 37-43.

Watkins, A. J.; W., Hillison, and S. E., Morecroft. 2004. Audit Quality: A Synthetis Theory and Empirical Evidence. Journal of Accounting Literature, 23: 153-194.

Wong, P. S. P., and Cheung, S. O. (2008). An Analysis of Relationship between Learning Behavior and Performance Improvement of Contracting Organizations. International Journal Project Management, 26, $112-123$.

Wooten, T. C. (2003). Research about Audit Quality. The CPA Journal, (Jan.) 71 (1), 48-52

Yetmar, S. A. (2005). Tax Practitioners' Ethical Sensitivity: A Model and Emprical Examination. Journal of Business Finance \& Accounting, 32, 1171-1196.

Yudistira, G. (2018). Siaran Pers OJK Kenakan Sanksi Terhadap Akuntan Publik dan Kantor Akuntan Publik Auditor PT Sunprima Nusantara Pembiayaan. Kontan.co.id. 